This full text version, available on TeesRep, is the PDF (final version) of:

Rahman, K. S. M. and Gakpe, E. (2008) 'Production, characterisation and applications of biosurfactants - Review', Biotechnology, 7 (2), pp.360-370.

For details regarding the final published version please click on the following DOI link:

http://dx.doi.org/10.3923/biotech.2008.360.370

When citing this source, please use the final published version as above.

This document was downloaded from http://tees.openrepository.com/tees/handle/10149/93896 Please do not use this version for citation purposes.

All items in TeesRep are protected by copyright, with all rights reserved, unless otherwise indicated. 
Biotechnology 7 (2): 360-370, 2008

ISSN 1682-296X

(C) 2008 Asian Network for Scientific Information

\title{
Production, Characterisation and Applications of Biosurfactants-Review
}

\author{
Pattanathu K.S.M. Rahman and Edward Gakpe \\ School of Science and Technology, University of Teesside, Middlesbrough-TS13BA, UK
}

\begin{abstract}
Biosurfactants are surface active compounds released by microorganisms. They are biodegradable non-toxic and ecofreindly materials. In this review we have updated the information about different microbial surfactants. The biosurfactant production depends on the fermentation conditions, environmental factors and nutrient availability. The extraction of the biosurfactants from the cell-free supernatant using the solvent extraction procedure and the qualitative and quantitative analysis has been discussed with appropriate equipment details. The application of the biosurfactant includes biomedical, cosmetic and bioremediation. Rhamnolipid biosurfactants produced by Pseudomonas aeruginosa DS10-129 showed significant applications in the bioremediation of hydrocarbons in gasoline-spilled soil and petroleum oily sludge. Rhamnolipid biosurfactant enhanced the bioremediation process by releasing the weathered oil from the soil matrices and enhanced the bioavailability of hydrocarbons for microbial degradation. It is having potential applications in the remediation of hydrocarbon contaminated sites.
\end{abstract}

Key words: Rhamnolipid, fermentation, emulsification, bioremediation, qualitative analysis, quantitative analysis

\section{INTRODUCTION}

Biosurfactants are amphiphilic biological compounds produced extracellularly or as part of the cell membrane by a variety of yeast, bacteria and filamentous fungi (Chen et al., 2007; Mata-Sandoval et al., 1999, 2000) from various substances including sugars, oils and wastes. However, carbohydrates and vegetable oils are among the most widely used substrates for research on biosurfactant production by Pseudomonas aeruginosa strains (Rahman et al., 2002a, b, 2003; Raza et al., 2007). The amphiphiles that form micelles can be potentially used for surface chemical works, are termed as SURFace ACTive AgeNTS or SURFACTANTS. Soaps and detergents can be described as having similar characteristics as surfactants. All surfactants have two ends namely, a hydrocarbon part which is less soluble in water (hydrophobic end). The hydrophobic part of the molecule is a long-chain of fatty acids, hydroxy fatty aids, hydroxyl fatty acids or $\alpha$-alkyl- $\beta$-hydroxy fatty acids. The water soluble end (hydrophilic) can be a carbohydrate, amino acid, cyclic peptide, phosphate, carboxylic acid or alcohol. Additionally, the hydrophobic moiety is usually a C8 to C22 alkyl chain or alkylaryl that may be linear or branched (Van Ginkel, 1989).

The unique properties of biosurfactants allow their use and possible replacement of chemically synthesised surfactants in a number of industrial operations
(Kosaric, 1992). Biosurfactants reduce surface tension, Critical Micelle Concentration (CMC) and interfacial tension in both aqueous solutions and hydrocarbon mixtures (Rahman et al., 2002c, d; Banat, 1995).

\section{GENERAL CLASSIFICATION OF BIOSURFACTANTS}

Surfactants can be classified according to the nature of the charge on individual polar moiety. Anionic surfactants are negatively charged usually due to a sulphonate or sulphur group. Non-ionic surfactants lack ionic constituent and the majority of all non-ionics are polymerisation products of 1, 2-epoxyethane. Cationic surfactants are characterised by a quaternary ammonium group which is positively charged. Lastly, amphoteric surfactants have both positively and negatively charged moieties in the same molecule (Van Ginkel, 1989). Biosurfactants can also be grouped into two categories namely; low-molecular-mass molecules with lower surface and interfacial tensions and high-molecular-mass polymers, which bind tightly to surfaces (Rosenberg and Ron, 1999). Examples of low-molecular-mass molecules are rhamnolipids (Lang and Wullbrandt, 1999; Cohen and Exerowa, 2007), sophorolipids (Davila et al., 1997) whilst food emulsifiers (Sheperd et al., 1995) and biodispersan (Rosenberg, 1993) are some of the examples of highmolecular-mass polymers.

Corresponding Author: Dr. Pattanathu K.S.M. Rahman, School of Science and Technology, University of Teesside, Middlesbrough-TS13BA, Tees Valley, United Kingdom

Tel: +44 (0)1642342429 Fax: +44(0) 1642384418 


\begin{tabular}{|c|c|}
\hline Type of biosurfactant & Microorganism \\
\hline Trehalose lipids & $\begin{array}{l}\text { Arthrobacter paraffineus } \\
\text { Corynebacterium } \mathrm{sp} . \\
\text { Mycobacterium } \mathrm{sp} . \\
\text { Rhodococcus erythropolis, Norcardia sp. }\end{array}$ \\
\hline Rhamnolipids & $\begin{array}{l}\text { Pseudomonas aeruginosa } \\
\text { Pseudomonas sp., Serratia rubidea }\end{array}$ \\
\hline Sophorolipids & $\begin{array}{l}\text { Condida apicola, Candida bombicola } \\
\text { Condida lipolytica } \\
\text { Candida bogoriensis }\end{array}$ \\
\hline Glycolipids & $\begin{array}{l}\text { Alcanivorax borkumensis } \\
\text { Arthrobacter sp., Coryne bacterium } \mathrm{sp} . \\
\text { R. erythropolis, Serratia marcescens } \\
\text { Tsukamurella sp. }\end{array}$ \\
\hline Cellobiose lipids & Ustilago maydis \\
\hline Polyol lipids & $\begin{array}{l}\text { Rhodotorula glutinus } \\
\text { Rhodotorula graminus }\end{array}$ \\
\hline Diglycosyl diglycerides & Lactobacillus fermentii \\
\hline Lipopolysaccharides & $\begin{array}{l}\text { Acinetoc bacter calcoaceticus (RAG1) } \\
\text { Pseudomonas sp., Candida lipolytica }\end{array}$ \\
\hline Arthrofactin & Arthrobacter sp., \\
\hline $\begin{array}{l}\text { Lichenysin A, Lichenysin B } \\
\text { Surfactin }\end{array}$ & $\begin{array}{l}\text { Bacillus licheniformis } \\
\text { Bacillus subtilis, Bacillus pumilus }\end{array}$ \\
\hline Viscosin & Pseudomonas fluorescens \\
\hline Ornithine, lysine peptides & $\begin{array}{l}\text { Thiobacillus thiooxidans } \\
\text { Streptomyces sioyaensis } \\
\text { Gluconobacter cerinus }\end{array}$ \\
\hline Phospholipids & Acinetocbacter sp. \\
\hline Sulfonylipids & $\begin{array}{l}\text { T. thiooxidans } \\
\text { Corynebacterium alkanolyticum }\end{array}$ \\
\hline $\begin{array}{l}\text { Fatty acids } \\
\text { (Corynomy colic acids, } \\
\text { spiculisporic acids, etc.) }\end{array}$ & $\begin{array}{l}\text { Capnocytophaga sp. } \\
\text { Penicillium spiculisporum } \\
\text { Corynebacterium lepus } \\
\text { Arthrobacter paraffineus } \\
\text { Talaramyces trachyspermus } \\
\text { Norcadia erythropolis }\end{array}$ \\
\hline Alasan & Acinetobacter radioresistens \\
\hline Streptofactin & Streptomyces tendae \\
\hline Particulate surfactant (PM) & Pseudomonas marginalis \\
\hline Biosur PM & Pseudomonas maltophila \\
\hline
\end{tabular}

Various micro-organisms are known to produce specific kind of biosurfactants. This depends on mainly the molecular composition of the type of biosurfactant produced. For instance, Pseudomonas aeruginosa DS10-129 was used to produce rhamnolipid (Rahman et al., 2002a, b, 2003), sophorose lipid by Torulopsis bombicola and Bacillus subtilis ATCC 2132 which was used by Davis et al. (2001) to produce surfactin. Kosaric (1992) classified biosurfactants based on their structure namely; hydroxylated and cross-linked fatty acids, polysaccharide-lipid complexes, glycolipids, lipoproteins-lipopeptides, phospholipids and complete cell surfaces. On the other hand, Biermann et al. (1987) group biosurfactants as glycolipids, lipopeptides, phospholipids, fatty acids, neutral lipids, polymeric and particulate compounds (Table 1). Lastly, Healy et al. (1996) group biosurfactants into four main categories namely, glycolipids, phospholipids, lipoproteins/ lipopepetides and polymeric.

\section{TYPES OF BIOSURFACTANTS}

There are many types of biosurfactants each produced by a specific micro-organism. The following are some of the various types of biosurfactants.

Glycolipids: Most known biosurfactants are glycolipids. They consist of mono-, di-, tri- and tetrasaccharides which include glucose, mannose, galactose, glucuronic acid, rhamnose and galactose sulphate. The fatty acid component usually has a composition similar to that of phospholipids of the same micro-organism (Veenanadig et al., 2000; Chen et al., 2007). Also, they are made up of carbohydrates in combination with long-chain aliphatic acids or hydroxyaliphatic acids (Desai and Banat, 1997). Among the glycolipids, the best known are the rhamnolipids, trehalolipids and sophorolipids (Desai and Banat, 1997; Karanth et al., 1999) and the best-studied glycolipid bioemulsifiers, rhamnolipds, trehalolipids and sophorolipids are disaccharides that are acylated with long-chain fatty acids or hydroxyl fatty acids (Rosenberg and Ron, 1999).

Rhamnolipids: Bacteria of the genus Pseudomonas are known to produce glycolipid surfactant containing rhamnose and 3-hydroxy fatty acids (Lang and Wullbrandt, 1999; Rahman et al., 2002b). Rhamnolipids produced by Pseudomonas aeruginosa have been widely studied and reported as a mixture of homologous species $\mathrm{RL} 1\left(\mathrm{RhC}_{10} \mathrm{C}_{10}\right), \mathrm{RL} 2\left(\mathrm{RhC}_{10}\right), \mathrm{RL} 3\left(\mathrm{Rh}_{2} \mathrm{C}_{10} \mathrm{C}_{10}\right)$ and RL4 $\left(\mathrm{Rh}_{2} \mathrm{C}_{10}\right)$ (Syldatk and Wagner, 1987; Lang and Wagner, 1987; Rahman et al., 2002b). Using virgin olive oil (Healy et al., 1996), a rhamnolipid was produced by Pseudomonas fluorescens NCIMB 11712 that is a methyl pentose monosaccharide. Disaccharide rhamnolipids are formed by condensing two moles of rhamnose sugar and an acetal group links the hydrophobic group. However, the lipid part of the molecule contains ester and carboxyl groups. Rhamnolipids produced by Pseudomonas aeruginosa strains are among the most effective surfactants when applied for the removal of hydrophobic compounds from contaminated soils (Rahman et al., 2006). They posses low average minimum surface tension of (30-32 $\mathrm{mN} \mathrm{m}^{-1}$ ); high average emulsifying activity of (10.4-15.5 U $\mathrm{mL}^{-1}$ filtrate), low critical micelle concentration (CMC) (5-65 mg L $\left.{ }^{-1}\right)$ and high affinity for hydrophobic organic molecules (Van Dyke et al., 1993).

Sophorolipids: They are group of biosurfactants produced by Torulopsis sp. Sophorolipids (SLs) consist of a dimeric sugar (sophorose) and a hydroxyl fatty acid, 
linked by a $\beta$-glycosidic bond (Asmer et al., 1988). According to $\mathrm{Hu}$ and $\mathrm{Ju},(2001)$ there are two types of SLs namely, the acidic (non-lactonic) SLs and the lactonic SLs. The hydroxyl fatty acid moiety of the acidic SLs has a free carboxylic acid functional group whilst that of the lactonic SLs forms a macrocyclic lactone ring with the 4"-hydroxyl group of the sophorose by intramolecular esterificaion. Until recently, lactonic SLs have been reported to have attracted more commercial and scientific attention than their acidic counterparts. They have measurable biocide activity (Lang et al., 1989), whilst the acetylated lactonic SLs have been applied in cosmetics as antidandruff, bacteriostatic agents and deodorants (Mager et al., 1987).

Trehalolipids: Another group of glycolipids are the trehalolipids, the serpentine group seen in many members of the genus Mycobacterium is due to the presence of trehalose esters on the cell surface (Asselineau and Asselineau, 1978). Disaccharide trehalose linked at C-6 and C-6 to mycolic acid is associated with most species of Mycobacterium, Norcardia and Corynebacterium. Mycolic acids are long-chain, $\alpha$-branched- $\beta$-hydroxy fatty acids. Trehalolipids from different organisms differ in the size and structure of mycolic acid, the number of carbon atoms and the degree of unsaturation (Desai and Banat, 1997). Trehalose lipids from Rhodococcus erythropolis and Arthrobacter sp. were found to lower the surface and interfacial tensions in culture broth from 25-40 and 1-5 $\mathrm{mN} \mathrm{m}^{-1}$, respectively (Li et al., 1984).

Lipoproteins and Lipopeptides: Lipopepetides called surfactin are produced by Bacillus sp. containing seven amino acids bonded to a carboxyl and hydroxyl groups of a 14-carbon acid. Surfactin just as any other biosurfractant reduces surface tension from $72-27 \mathrm{mN} \mathrm{m}^{-1}$ with concentrations as low as $0.005 \%$, making surfactin one of the most powerful biosurfactants (Kakinuma et al., 1969). The cyclic lipopeptide surfactin produced by Bacillus subtilis ATCC 21332 is an example of one of the most powerful biosurfactants. Another important characteristic of surfactin is its ability to lyse mammalian erythrocytes and to form spheroplasts (Bernheimer and Avigad, 1970). This property is been used to detect surfactin production through haemolysis on blood agar.

Fatty acids: Fatty acids produced from alkanes as a result of microbial oxidations have been considered as surfactants (Rehn and Reiff, 1981). In addition to the straight-chain acids, micro-organisms produce complex fatty acids containing $\mathrm{OH}$ groups and alkyl branches.
Examples of such complex acids include Corynomucolic acids that are also surfactants (Kretschner et al., 1982). The hydrophilic or lipophilic balance of fatty acids is clearly related to the length of the hydrocarbon chain. For lowering surface and interfacial tensions, the most active saturated fatty acids are in the range of $\mathrm{C} 12-\mathrm{C} 14$ (Rosenberg and Ron, 1999).

Phospholipids: Phospholipids are known to form major components of microbial membranes. When certain hydrocarbon-degrading bacteria or yeast are grown on alkane substrates, the level of phospholid increases greatly. For instance, using hexadecane-grown Acinetobacter sp. HOl-N, phospholipids (mainly phosphatidylethanolamine) rich vesicles were produced (Kaeppeli and Finnerty, 1979). Phospholipids have been quantitatively produced from Thiobacillus thiooxidans that are responsible for wetting elemental sulphur necessary for growth (Beeba and Umbriet, 1971). Phosphatidylethanolamine produced by Rhodococcus erythropolis grown on n-alkane resulted in the lowering of interfacial tension between water and hexadecane to less than $1 \mathrm{mN} \mathrm{m}^{-1}$ and CMC of $30 \mathrm{mg} \mathrm{L}^{-1}$ (Kretschner et al., 1982).

Polymeric biosurfactants: Emulsan, liposan, mannoprotein and polysaccharide-protein complexes are known to be the best-studied polymeric biosurfactants (Desai and Banat, 1997). Using Acinetobacter calcoaceticus RAG-1, Rosenberg et al. (1979) extracted a potent polyanionic amphipathic heteropolysaccharide bioemulsifier called emulsan. It is a very effective emulsifying agent for hydrocarbons in water even at a concentration as low as $0.001-0.01 \%$. Additionally, it is noted as one of the most powerful emulsion stabilizers known with the ability to resist inversion even at a waterto-oil ratio of 1:4 (Zosim et al., 1982). Ciriglian and Carman (1984) synthesised liposan, an extracellular water-soluble emulsifier using Candida lipolytica. It is composed of $83 \%$ carbohydrate and $17 \%$ protein with the carbohydrate portion being a heteropolysaccharide consisting of glucose, galactose, galactosamine and galactoronic acid. Cameron et al. (1988) demonstrated the production of large amounts of mannoprotein by Saccharomyces cerevisiae. When purified, the emulsifier contains $44 \%$ mannose and $17 \%$ protein. The mannoprotein exhibited excellent emulsifying activity toward several oils, alkanes and organic solvents. Other polymeric biosurfactants such as biodispersan, alasan, food emulsifiers, protein complexes and insectides emulsifiers have also been reported. 


\section{BIOSURFACTANT PRODUCTION}

Biosurfactants are usually produced extracellularly or as part of cell membrane by yeast, bacteria or filamentous fungi (Mata-Sandoval et al., 1999). Different kinds of bacteria have been employed by many researchers in producing biosurfactant using culture media. Most of such bacteria used are isolated from contaminated sites usually containing petroleum hydrocarbon by products and/or industrial wastes (Rahman et al., 2006; Benincasa 2007).

Factors affecting biosurfactant production: A number of factors affect the production of biosurfactants. These factors include environmental factors as well as source of carbon substrate among others.

Environmental factors: Biosurfactant production like any other chemical reaction is affected by a number of factors that either increase its productivity or inhibit it. Accordingly, environmental factors such as $\mathrm{pH}$, salinity and temperature affect biosurfactant production (Rahman et al., 2002b; Ilori et al., 2005; Raza et al., 2007). During In situ applications, bacteria for Microbially Enhanced Oil Recovery (MEOR) must be able to grow under extreme conditions encountered in oil reservoirs such as high temperature, pressure, salinity and low oxygen level. Additionally, it was found out that biosurfactant produced from Pseudomonas strains MEOR 171 and MEOR 172 were not affected by temperature, $\mathrm{pH}$ and $\mathrm{Ca}, \mathrm{Mg}$ concentration in the ranges found in many oil reservoirs (Karanth et al., 1999). Desai and Banat (1997) also affirm the fact that environmental factors and growth conditions such as $\mathrm{pH}$, temperature, agitation and oxygen availability also affect biosurfactant production through their effects on cellular growth or activity. Salt concentrations also affect biosurfactant production depending on its effect on cellular activity. Some biosurfactants however, were not affected by salt concentrations up to $10 \%$ $(\mathrm{w} / \mathrm{v})$, although slight reductions in the CMCs were detected (Abu-Ruwaida et al., 1991).

Carbon substrates for biosurfactant production: A number of carbon substrates have been used in many researches during biosurfactant production. Indeed the type, Quality and quantity of biosurfactant production are affected and influenced by the nature of the carbon substrate (Singer, 1985; Raza et al., 2007). Diesel and crude oil were identified to be good sources of carbon for biosurfactant production by organisms (Ilori et al., 2005). Other water soluble compounds such as glucose, sucrose and glycerol have also been reported to be a source of carbon substrate for biosurfactant production (Desai and Banat, 1997; Rahman et al., 2002a). In the treatment of wastewater (Pagilla et al., 2002) used soluble acetate and sparingly soluble hexadecane as carbon substrate for Gordonia amarae growth and biosurfactant production in large scale batch reactors. It has become evident that the importance of carbon substrates does have a major role to play on the biosurfactant production. It was noted that carbon sources such as nutrient concentrations, $\mathrm{pH}$ and age of the culture affects the yield of rhamnolipid production. On a positive note, hydrophobic substrates like corn oil, lard (rich in unsaturated and saturated fat) and long chain alcohols maximized biosurfactant production (100-165 $\mathrm{mg} \mathrm{g}^{-1}$ substrate). Contrarily, hydrophilic substrates like glucose and succinate delivered poor yields (12-36 $\mathrm{mg} \mathrm{g}^{-1}$ substrate) (Mata-Sandoval et al., 2000). Lastly, Robert et al. (1989) attests to the fact that Pseudomonas aeruginosa can be produced from a variety of carbon sources such as C11 and C12 alkanes, succinate, pyruvate, citrate, fructose, glycerol, olive oil, glucose and mannitol.

Estimation of biosurfactant activity: This involves measuring the changes in surface and interfacial tensions, stabilization/destabilization of emulsions and hydrophiliclipophilic balance (HLB). Using a tensiometer, the surface tension at air/water and oil/water interfaces can be easily determined. The surface tension of distilled water is noted to be $72 \mathrm{mN} \mathrm{m}^{-1}$ and an addition of biosurfactant lowers it to as low as $28 \mathrm{mN} \mathrm{m}^{-1}$ (Rahman et al., 2006). Thus adding a biosurfactant to water reduces its surface tension to a critical level above which amphiphilic molecules readily form supramolecular structures like micelles, bilayers and vesicles known as Critical Micelle Concentration (CMC). CMC is therefore defined as the ability of a biosurfactant within an aqueous phase and is commonly used to measure the efficiency of a biosurfactant (Desai and Banat, 1997).

Analytical methods: A number of analytical methods have been employed by many researchers in their analyses and in some cases characterisation of biosurfactants. In the Table 2, the type of biosurfactant, bacteria, solvent, supporting references and type of analytical method used are shown. 
Biotechnology 7 (2): 360-370, 2008

Table 2: Analytical methods used for the qualitative and quantitative analysis of biosurfactant

\begin{tabular}{|c|c|c|c|}
\hline Biosurfactant and bacteria & $\begin{array}{l}\text { Analytical } \\
\text { method }\end{array}$ & Chemicals/Solvents required & Reference \\
\hline \multicolumn{4}{|l|}{ Rhamnolipids } \\
\hline \multirow[t]{13}{*}{ Pseudomonas aeruginosa } & TLC & $\mathrm{CHCl}_{3} / \mathrm{CH}_{3} \mathrm{OH} / \mathrm{CH}_{3} \mathrm{COOH}$ & Arinoet al. (1996) \\
\hline & HPLC & $\mathrm{CHCl}_{3} / \mathrm{CH}_{3} \mathrm{OH}$ & Rahman et al. (2002b) \\
\hline & HPLC & $\mathrm{CH}_{3} \mathrm{CN}$ & Chayabutra et al. (2001) \\
\hline & & 2-Propanol- $\mathrm{NH}_{4} \mathrm{OH}-\mathrm{H}_{2} \mathrm{O}$ & Chayabutra et al. (2001) \\
\hline & Westem blot & & Olvera et al. (1999) \\
\hline & TLC & Carbenicillin, Tetracycline & Olvera et al. (1999) \\
\hline & HPLC & $\mathrm{CH}_{3} \mathrm{CN}-\mathrm{H}_{2} \mathrm{O}$ & Schenk et al. (1995) \\
\hline & HPLC & Tetrahy drofuran $-\mathrm{H}_{2} \mathrm{O}$ & Sekelsky and Shreve (1999) \\
\hline & HPLC & $\mathrm{CH}_{3} \mathrm{CN} /$ Phosphate buffer $\mathrm{pH} 6$ & Wild et al. (1997) \\
\hline & TLC & $\mathrm{CH}_{3} \mathrm{OH} / \mathrm{H}_{2} \mathrm{O}$ & Rahman et al. (1999) \\
\hline & FTIR & & Wu and Ju (1998) \\
\hline & TLC & Solv. A: $\mathrm{CHCl}_{3} / \mathrm{CH}_{3} \mathrm{OH} / \mathrm{CH}_{3} \mathrm{COOH}$ & Wu and Ju (1998) \\
\hline & & Solv. B: 2-Propanol- $\mathrm{NH}_{4} \mathrm{OH}-\mathrm{H}_{2} \mathrm{O}$ & Wu and Ju (1998) \\
\hline \multirow[t]{2}{*}{ P. aeruginasa LBI } & HPLC & $\mathrm{CH}_{3} \mathrm{CN} / \mathrm{H}_{2} \mathrm{O}$ & Benincasa et cl. (2002) \\
\hline & TLC & $\mathrm{CHCl}_{3} / \mathrm{CH}_{3} \mathrm{OH} / \mathrm{H}_{2} \mathrm{O}$ & Benincasa et al. (2002) \\
\hline \multirow[t]{2}{*}{ P. aeruginosa 57RP } & HPLC-MS & $\mathrm{CH}_{3} \mathrm{CN} / \mathrm{H}_{2} \mathrm{O}$ & Deziel et al. (2000) \\
\hline & TLC & $\mathrm{CHCl}_{3} / \mathrm{CH}_{3} \mathrm{OH} / \mathrm{CH}_{3} \mathrm{COOH}$ & Deziel et al. (2000) \\
\hline \multirow[t]{3}{*}{ P. aeruginosa UG2 } & HPLC & $\mathrm{CH}_{3} \mathrm{CN}-\mathrm{H}_{3} \mathrm{PO}_{4}$ & Mata-Sandoval et al. (2000) \\
\hline & ESI & $\mathrm{N}_{2}$ & Mata-Sandoval et al. (2000) \\
\hline & HPLC-UV & $\mathrm{CH}_{3} \mathrm{CN}-\mathrm{H}_{3} \mathrm{PO}_{4}$ & Mata-Sandoval et al. (1999) \\
\hline \multirow[t]{2}{*}{ P. aeruginosa 47T2 } & HPLC & $\mathrm{CH}_{3} \mathrm{CN} / \mathrm{CH}_{3} \mathrm{COOH}$ & Haba et al. (2000) \\
\hline & TLC & $\mathrm{CHCl}_{3} / \mathrm{CH}_{3} \mathrm{OH} / \mathrm{CH}_{3} \mathrm{COOH}$ & Haba et al. $(2000)$ \\
\hline P. fluorescens & TLC & $\mathrm{CH}_{3} \mathrm{CN} / \mathrm{H}_{2} \mathrm{O}$ & Caldini et al. (1995) \\
\hline \multicolumn{4}{|l|}{ Lpopeptide } \\
\hline \multirow[t]{2}{*}{ Bacillus licheniformis } & FTIR & & Thaniyavarn et al. (2003) \\
\hline & HPLC-MS & $\mathrm{CH}_{3} \mathrm{CN} / \mathrm{TFA}$ & Thaniyavarn et al. (2003) \\
\hline \multicolumn{4}{|l|}{ Sophorolipid } \\
\hline Candida bombicola & HPLC with ELSD & & Davila et al. (1997) \\
\hline \multirow{2}{*}{ Torulopsis sp. } & HPLC-UV & $\mathrm{CH}_{3} \mathrm{CN} / \mathrm{H}_{2} \mathrm{O}$ & $\mathrm{Hu}$ and $\mathrm{Ju}(2001)$ \\
\hline & FTIR & & $\mathrm{Hu}$ and $\mathrm{Ju}(2001)$ \\
\hline \multicolumn{4}{|l|}{ Phospholipid } \\
\hline Acinetobacter sp. & GC-MS & $\mathrm{CHCl}_{3} / \mathrm{CH}_{3} \mathrm{OH}$ (Extraction Method) & Koma et al. (2001) \\
\hline \multicolumn{4}{|l|}{ Trehalose lipid } \\
\hline Rhodococcus sp. $\mathrm{P} 32 \mathrm{Cl}$ & HPLC & $\mathrm{CH}_{3} \mathrm{CN}$ & Maghsoudi et al. (2001) \\
\hline \multicolumn{4}{|l|}{ Surfactin } \\
\hline Bacillus subtilis ATCC 21332 & HPLC & $\mathrm{CH}_{3} \mathrm{CN} / \mathrm{TFA}$ & Davis et al. (2001) \\
\hline
\end{tabular}

\section{APPLICATIONS OF BIOSURFACTANT}

A number of applications of biosurfactants have been researched into and published. Its usefulness to man in most aspects of human life can not be over emphasised. The enormous market demand for surfactants is currently met numerous synthetic, mainly petroleum-based chemical surfactants. These compounds are usually toxic to the environment and as well as been non-biodegradable. Furthermore, they may bio-accumulate and their production, processes and by-products can be environmentally hazardous. It has become necessary that tightening environmental regulations and increasing awareness for the need to protect the ecosystem have effectively resulted in an increasing interest in biosurfactants as possible alternates to chemical surfactants (Banat et al., 2000; Benincasa, 2007). Biosurfactants are beginning to acquire a status as potential performance-effective molecules in various fields. Presently, biosurfactants are mainly used in studies on enhanced oil recovery and hydrocarbon bioremediation (Rahman et al., 2004, 2006). The worldwide production of surfactants amounted to 17 million metric tonnes (t) in 2000 (including soaps) with expected future growth rates of $3-4 \%$ year $^{-1}$ globally and $1.5-2.0 \%$ in the $\mathrm{EU}$ (Whalley, 1995). Industrial applications of surfactants are classified according to how they are applied. These are surfactants used in detergents and cleaners (54\%); as auxiliaries for textiles, leather and paper (13\%); in chemical processes $(10 \%)$; in cosmetics and pharmaceuticals $(10 \%)$; in the food industry $(3 \%)$; in agriculture $(2 \%)$ and in others $(8 \%)$.

Biosurfactants and bioremediation: Oil spillage during offshore production (drilling) and its transport from one location to another is seriously affecting aquatic life. An explicit example is the massive oil spillage as well as release during the Gulf War from 1991 to 1992. It was estimated that some 11 million barrels of oil was released into the Arabian Gulf from January to May 1991, polluting 
more than 800 miles of Kuwait and Saudi Arabian coastline. The cost of clean-up has been estimated at more than $\$ 700$ million. The oil released in to the Gulf produced devastating consequences on the marine wildlife of the area, including endangering hawksbill and green turtles, thousands of cormorants (a type of marine bird) as well as 400-500 tons of fishes died in the Gulf as a result of exposure to oil or polluted water. Additionally, (Shaw, 1992; Burns et al., 1993; Burger, 1993) it was identified that several oil pollution accidents at high seas and on beaches have resulted in enormous ecological and social catastrophes. Rahman et al. (2003, 2004, 2006) examined the bioremediation of n-alkanes in petroleum sludge containing an oil and grease content of $87.4 \%$. Remarkably, $10 \%$ of the sludge constituting C8-C11 alkanes were degraded 100\%; whilst C12-C21, 83-98\%; C22-C31 between 80-85\% and finally C32-C40, 57-73\% after 56 days with addition of a bacterial consortium, nutrients and rhamnolipids. In another experiment, (Hayes et al., 1986) demonstrated that when Boscan Venezuelan heavy crude oil was treated with emulsan, oil viscosity was reduced from 200,000 to $100 \mathrm{Cp}$. Hence, it became visible to pump heavy oil 26,000 miles in a commercial pipeline after this treatment although conventional chemical surfactant treatment failed. Biosurfactants are also used in bioremediation of sites contaminated with toxic heavy metals like uranium, cadmium and lead (Miller, 1995; Mulligan and Wang, 2006). Shafeeq et al. (1989) showed that hexadecane, octadecane and nanodecane incubated for a 28 day period under laboratory conditions with the Pseudomonas aeruginosa isolate S8 obtained from oil-polluted sea water degraded the hydrocarbons by $47,58,73$ and $60 \%$, respectively. The application of rhamnolipid produced by Pseudomonas aeruginosa DS10-129 along with poultry litter and coir pith enhanced ex situ bioremediation of a gasoline-contaminated soil (Rahman et al., 2002a). Benzene, toluene, ethylbenzene, xylene and trimethylbenzene were degraded according to Kosaric (2001) by adding microbial consortium to soil contaminated with gasoline and enriched with nutrients and oxygen.

Other biosurfactant applications: Biosurfactants have also been applied in food industries usually as food additives (emulsifiers). For instance, lectin and its derivatives, fatty acid esters containing glycerol, sorbitan or ethylene glycol and ethoxylated derivatives of monoglycerides including recently synthesized oligopeptide (Bloomberg, 1991). These emulsifiers have a long way to improving the flavour, taste and quality of products with minimal health hazards. The agriculture industry has also benefited from the production of biosurfactants. Stanghellini and Miller (1997) demonstrated that rhamnolipids are highly effective against three representative genera of zoosporic plant pathogens; Pythium aphanidermatum, Phytophthora capsici and Plasmopara lactucea-radicis. Hence, purified mono-and di-rhamnolipids with concentrations ranging from 5-30 $\mathrm{mg} \mathrm{L}^{-1}$ caused cessation of motility and lys is of the entire zoospore population in less than $1 \mathrm{~min}$. Bioemulsifiers are potentially used in various formulations of herbicides and pesticides (Rosenberg and Ron, 1999). An example is the use of bioemulsifiers (glycolipopeptides) produced by strains of Bacillus for emulsifying immiscible organophosphorus pesticides (Patel and Gopinathan, 1986). Biosurfactant applications in cosmetic and pharmaceutical industries have also been reported (Cameotra and Makkar, 2004).

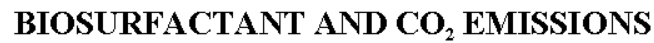

Greenhouse effect is a naturally occurring process that aids in heating the earth's surface and atmospheric gases such as $\mathrm{CO}_{2}$, water vapour and methane that are able to change the energy balance of the planet by absorbing long wave radiation (infra red) emitted from the earth's surface. Studies have shown that biosurfactants a have a role to play in the reduction, if not total elimination of $\mathrm{CO}_{2}$ emission into the atmosphere. No

Table 3: Potential to substitute petrochemical by oleochemical surfactants in the EU by 2010 (Patel, 2004)

\begin{tabular}{lrrr}
\hline & $\begin{array}{l}\text { EU } \\
\text { production } \\
1998(\mathrm{kt})\end{array}$ & $\begin{array}{l}\text { High RRM } \\
\text { scenario } \\
2010(\mathrm{kt})\end{array}$ & $\begin{array}{c}\text { Change } \\
(\%)\end{array}$ \\
Surfactants & & & \\
\hline Anionic & 409 & 409 & 0 \\
LAS-Pc & 69 & 69 & 0 \\
SAS-Pc & 43 & 16 & -63 \\
AS-Pc & 64 & 91 & 42 \\
AS-Oleochemical & 74 & 37 & -50 \\
AEsS-Pc & 172 & 209 & 21 \\
AES-Oleochemical & 47 & 28 & -42 \\
Other anionics-Pc & 32 & 51 & 63 \\
Other anionics-Oleochemical & & & \\
Non-ionic & 255 & 128 & -50 \\
AE-Pc & 383 & 510 & 33 \\
AE-Oleochemical & 26 & 26 & 0 \\
Other-ethoxylates-Pc* & 233 & 233 & 0 \\
Other-ethoxylates-Oleochemical $\dagger$ & 1,807 & 1,807 & - \\
Total & $884(49 \%)$ & $1,095(61 \%)$ & +24 \\
Oleochemical surfactants & $923(51 \%)$ & $712(39 \%)$ & -23 \\
Petrochemical surfactants & & & \\
\hline
\end{tabular}

This table covers only the most important surfactants while cationic, amphoteric and some of the nonionic surfactants are excluded, $\mathrm{RRM}=$ Renewable raw materials; $\mathrm{AE}=$ Alcohol ethoxylate; AES = Alcohol ether sulphate; AS = Alcohol sulphate; LAS = Linear alkylbenzene sulphate; $\mathrm{Pc}=$ Petrochemical feedstock; $\mathrm{PKO}=$ Palm kernel oil; $\mathrm{CNO}=$ Coconut oil; $\mathrm{PO}=$ Palm oil; $\mathrm{SAS}=$ Secondary alkane sulphonate, * Containing 7 ethy lene oxide (EO) units on average, $†$ Average of 7 EO units based on PKO and CNO and 11 EO units based on PO 
wonder the 1997 UNFCCC Kyoto Protocol was adopted to curtail the emission of greenhouse gases (United Nations Framework Convention on Climate Change, 1997). Assuming that the total surfactant production remains constant until 2010 in EU, it was estimated that the amount of oleochemical surfactants could be increased from about $880 \mathrm{kt}$ in 1998 to approximately $1,100 \mathrm{kt}$ in 2010 , an increase of $24 \%$. This substitution reduces the life- cycle $\mathrm{CO}_{2}$ emissions from surfactants by $8 \%$. The theoretical maximum potential for total substitution is $37 \%$ (Table 3). Since the surfactant market is expected to grow, the avoided emissions are expected to exceed $8 \%$ of the current life-cycle $\mathrm{CO}_{2}$ emissions from surfactants. Furthermore, in 1998, an estimated 1.5 million tons of $\mathrm{CO}_{2}$ emissions were avoided by the production of oleochemical surfactants (Patel, 2004).

\section{MERITS OF BIOSURFACTANTS}

Researches have shown that biosurfactants exhibit many advantages over chemically synthesized surfactants. The following are some of the advantages of biosurfactants (Kosaric, 1992; Mulligan and Wang, 2006).

- Biodegradability: Biosurfactants are easily degraded by bacteria and other microscopic organisms; hence they do not pose much threat to the environment.

- Generally low toxicity: For instance glycolipids from Rhodococcus sp. $413 \mathrm{~A}$ were $50 \%$ less toxic than Tween 80 in naphthalene solubilization tests (Kanga et al., 1997).

- Biocompatibility and digestibility: This ensures their application in cosmetic, pharmaceuticals and as functional food additives.

- Availability of raw material: Biosurfactants can be produced from cheap raw materials that are available in large quantities.

- Acceptable production economics: Depending on its application, biosurfactants can also be produced from industrial wastes and by-products and this is of particular interest for their bulk production.

- Use in environmental control: Biosurfactants can be efficiently used in handling industrial emulsions, control of oil spills, biodegradation and detoxification of industrial effluents and bioremediation of contaminated soil.

- Specificity: Biosurfactants being complex organic molecules with specific functional groups are often specific in their action. This would be of particular interest in detoxification of specific pollutants, deemulsification of industrial emulsions, specific cosmetic, pharmaceutical and food applications.

\section{DEMERITS OF BIOSURFACTANTS}

Despite the numerous advantages that biosurfactants have been known to exhibit, it is also known to have the following associate demerits (Kosaric, 1992).

- Large scale production of biosurfactants may be expensive. However this problem could be overcome by coupling the process to utilization of waste substrates, combating at the same time their polluting effects that balance the overall costs.

- There is difficulty in obtaining pure substances (biosurfactants), which is of particular importance in pharmaceutical, food and cosmetic applications. This is because downstream processing of diluted broths involved that may require multiple consecutive steps.

- Over producing strains of bacteria are rare and those found generally display a low productivity. In addition, complex media need to be applied to the sample.

- The regulation of biosurfactant synthesis is hardly understood, seemingly it represent secondary metabolite regulation. Thus considering a batch culture, secondary metabolite production begins when the culture is stressed due to the depletion of a nutrient. This phenomenon is closely correlated with the transition phase- slow growth rate of culture and with the morphological changes that this phase implies. Among others $\mathrm{O}_{2}$-limitation has been described as an essential parameter to govern biosurfactant production.

- An improvement of the production yield is hampered by the strong foam formation. Consequently, diluted media have to be applied and only immobilised systems provide an increased productivity of about $3 \mathrm{gl}^{-1} \mathrm{~h}^{-1}$ (Fiechter, 1992).

\section{CONCLUSIONS}

This review provides information about the biosurfactant production by microorganisms. The scaleup of biosurfactants for industrial production is still challenging. Since the composition of the final products is affected by the nutrient, micronutrient and environmental factors, it is obvious to find a right surfactant for industrial scale-up. In this review we have provided an overview about the availability of various analytical equipments to detect and quantify the biosurfactant. The requirement of the purity of the biosurfactants depends on the application, for example the surfactants used for environmental remediation 
should be free from microbial loading but the quality of the product could be compromised. But for pharmaceutical and cosmetic applications the biosurfactants should meet the requirement of various regulatory standards. Few organisms in the indigenous microbial flora are producing biosurfactants in the natural environment to adapt to various adverse conditions. We are just trying to exploit the process for the benefit of mankind. Still we need further understanding of the microbial physiology and genetics of these microorganisms to harness them for efficient industrial applications.

\section{ACKNOWLEDGMENTS}

The authors wish to thank the University Research Fund and University Enterprise Development Funds to support the biosurfactants research at the University of Teesside.

\section{REFERENCES}

Abu-Ruwaida, A.S., I.M. Banat, S. Hadirto, A. Saleem and M. Kadri, 1991. Isolation of biosurfactant producing bacteria-product characterisation and evaluation. Acta Biotechnol., 11 (4): 315-324.

Arino, S., R. Marchal and J. Vandecasteele, 1996. Identification and production of rhamnolipidic biosurfactant by Pseudomobas sp. Applied Microbiol. Biotechnol., 45 (1-2): 162-168.

Asmer, H.J., L. Slegmund, W. Fritz and V. Wrey, 1988. Microbial production, structure elucidation and bioconversion of sophorose lipid. JAOCS., 65: 1460-1466.

Asselineau, C. and J. Asselineau, 1978. Trehalose containing glycolipids. Prog. Chem. Fats Other Lipids, 16: 59-99.

Banat, I.M., 1995. Characterisation of biosurfactants and their use in pollution removal-state of art (review). Acta Biotechnol., 15: 251-267.

Banat, I.M., B.S. Makkar and S.S. Cameotra, 2000. Potential commercial applications of microbial surfactants. Applied Microbiol. Biotechnol., 53 (5): 495-508.

Beeba, J.L. and W.W.Umbriet, 1971. Extracellular lipids of Thiobacillus thiooxidans. J. Bacteriol., 108 (1): 612-615.

Benincasa, M., J. Contiero, M.A. Manresa and I.O. Moraes, 2002. Rhamnolipid production by Pseudomonas aeruginosa LBI growing on soapstock as the sole carbon source. J. Food Eng., 54 (4): 283-288.
Benincasa, M., 2007. Rhamnolipid produced from agroindustrial wastes enhances hydrocarbon biodegradation in contaminated soil. Curr. Microbiol., 54 (6): 445-449.

Bernheimer, A.W. and L.S. Avigad, 1970. Nature and properties of a cytological agent produced by Bacillus subtilis. J. Gen. Microbiol., 61: 361-369.

Biermann, M., F. Lange, R. Piorr, U. Ploog, H. Rutzen, J. Schindler and R. Schmidt, 1987. Surfactants in Consumer Products: Theory, Technology and Application. Falbe, J. (Ed.). Springer-Verlag, Heidelberg, pp: 86-106.

Bloomberg, G., 1991. Designing proteins as emulsifiers. Lebensmitte Technologie, 24: 130-131.

Burger, A.E., 1993. Estimating the mortality of seabirds following oil-spills-effects of spill volume. Mar. Pollut. Bull., 26 (3): 140-143.

Burns, K.A., S.D. Garrity and S.C. Levings, 1993. How many years until mangrove ecosystems recover from catastrophic oil-spills of crude oil. J. Exp. Mar. Biol. Ecol., 171: 273-295.

Caldini, G., G. Cenci, R. Manenti and G. Morozzi, 1995. The ability of an environmental isolate of Pseudomonas fluorescens to utilise chrysene and other four-ring polynuclear aromatic hydrocarbons. Applied Microbiol. Biotechnol., 44: 225-229.

Cameotra, S.S. and R.S. Makkar, 2004. Recent applications of biosurfactants as biological and immunological molecules. Curr. Opin. Microbiol., 7 (3): 262-266.

Cameron, D.R., D.G. Cooper and R.J. Neufeld, 1988. The mannoprotein of Saccharomyces cerevisiae is an effective bioemulsifier. Applied Environ. Microbiol., 54 (6): 1420-1425.

Chayabutra, C., J. Wu and L.K. Ju, 2001. Rhamnolipid production by Pseudomonas aeruginosa under denitrification: Effects of limiting nutrients and carbon substrates. Biotechnol. Bioeng., 72 (1): 25-33.

Chen, S.Y., Y.H. Wei and J.S. Chang, 2007. Repeated $\mathrm{pH}$-stat fed-batch fermentation for rhamnolipid production with indigenous Pseudomonas aeruginosa S2. Applied Microbiol. Biotechnol., $76(1): 67-74$.

Ciriglian, M.C. and G.M. Carman, 1984. Isolation of bioemulsifier from Candida lipolytica. Applied Environ. Microbiol., 48 (4): 747-750.

Cohen, R. and D. Exerowa, 2007. Surface forces and properties of foam films from rhamnolipid biosurfactants. Adv. Colloid Interfac., 135: 24-34.

Davila, A.M., R. Marchel and J.P. Vandecasteele, 1997. Sophorose lipid fermentation with differentiated substrate supply for growth and production phases. Applied Microbiol. Biotechnol., 47 (5): 496-501. 
Davis, D.A., H.C. Lynch and J. Varley, 2001. The application of foaming for the recovery of surfactin from Bacillus subtilis ATCC 21332 Cultures. Enzyme Microb. Technol., 28: 346-354.

Desai, J.D. and I.M. Banat, 1997. Microbial production of surfactant and their commercial potential. Microbiol. Mol. Biol. R., 61 (1): 47-64.

Deziel, E., F. Leptine, S. Milot and R. Villemur, 2000. Mass spectrometry monitoring of rhamnolipds from growing culture of Pseudomonas aeruginosa strain from 57RP. Biochim. Biophys. Acta., $1485(2-3)$ : 145-152.

Fiechter, A., 1992. Integrated systems for biosurfactant synthesis. Pure Applied Chem., 64 (11): 1739-1743.

Haba, E., M.J. Espuny, M. Busquets and A. Manresa, 2000. Screening and production of rhamnolipids by Pseudomonas aeruginosa 47T2 NCIB 40044 from waste frying oils. J. Applied Microbiol., 88 (3): 379-387.

Hayes, M.E., E. Nestaas and K.R. Hrebenar, 1986. Microbial surfactants. Chemtech, 16 (4): 239-243.

Healy, M.G., C.M. Devine and R. Murphy, 1996. Microbial production of biosurfactants. Resour. Conserv. Recy., 18 (1): 41-57.

$\mathrm{Hu}, \mathrm{Y}$. and L.K. Ju, 2001. Purification of lactonic sophorolipids by crystallization. J. Biotechnol., 87 (3): 263-272.

Ilori, M.O., C.J. Amobi and A.C. Odocha, 2005. Factors affecting the production of oil degrading Aeromonas sp. isolated from a typical environment. Chemosphere, 61 (7): 985-992.

Kaeppeli, O. and W.R. Finnerty, 1979. Partition of alkane by an extracellular vesicle derived from hexadecanegrown Acinetobacter. J. Bacteriol., 140 (2): 707-712.

Kakinuma, A., A. Oachida, T. Shina, H. Sugino, M. Isano, G. Tanura and K. Arima, 1969. Confirmation of the structure of surfactin by mass spectrometry. Agric. Biol. Chem., 33: 1669-1672.

Kanga, S.H., J.S. Bonner, C.A. Page, M.A. Mills and R.L. Autenrieth, 1997. Solubilization of naphthalene from crude oil using biosurfactants. Environ. Sci. Technol., 31: 556-561.

Karanth, N.G.K., P.G. Deo and N.K. Veenanadig, 1999. Microbial production of biosurfactants and their importance. Curr. Sci., 77 (1): 116-126.

Koma, D., F. Hasumi, E. Yamamoto, T. Ohta, S.Y. Chung and M. Kubo, 2001. Biodegradation of long-chain n-paraffins grown waste oil of car engine by Acinetobacter sp. J. Biosci. Bioeng., 91: 157-170.

Kosaric, N., 1992. Biosurfactants in industry. Pure Applied Chem., 64 (11): 1731-1737.
Kosaric, N., 2001. Biosurfactants and their application for soil bioremediation. Food Technol. Biotechnol., 39: 295-304.

Kretschner, A., H. Block and F. Wagner, 1982. Chemical and physical characterisation of interfacial-active lipids from Rhodococcus erythropolis grown on nalkane. Applied Environ. Microbiol., 44: 864-870.

Lang, S. and F. Wagner, 1987. Structure and Properties of Biosurfactants. In: Biosurfactants and Biotechnolog, Kosaric, N., W.L. Cairns and N.C.C. Gray (Eds.). Marcel Dekker, New York, pp: $21-45$.

Lang, S., E. Katsiwela and F. Wagner, 1989. Antimicrobial effects of biosurfactants. Fat Sci. Technol., 91 (9): 363-368.

Lang, S. and D. Wullbrandt, 1999. Rhamnose lipidsbiosynthesis, microbial production and application potential. Applied Microbiol. Biotechnol., $51(1): 22-32$.

Li, Z.Y., S. Lang, F. Wagner, L. Witte and V. Wray, 1984. Formation and identification of interfacialactive glycolipids from resting microbial cells of Arthrobacter sp. and potential use in tertiary oil recovery. Applied Environ. Microbiol., 48 (3): 610-617.

Mager, H., R. Roethlisbeger and F. Wagner, 1987. Preparation of sophorose lipid lactones for use in cosmetics, especially as antidandruff and bacteriostatic agents and deodorant. Germany Patent, De 3: 417.

Maghsoudi, S., M. Vossoughi, A. Kheirolomoom, E. Tanaka and S. Katoh, 2001. Biodesulfurisation of hydrocarbons and diesel fuels by Rhodococcus sp. Strain P32CI. Biochem. Eng. J., 8 (2): 151-156.

Mata-Sandoval, J.C., J. Karns and A. Torrents, 1999. High-performance liquid chromatography method for the characterisation of rhamnolipid mixtures produced by Pseudomonas aeruginosa UG2 on corn oil. J. Chromatogr. A., 864 (2): 211-220.

Mata-Sandoval, J.C., J. Karns and A. Torrents, 2000. Effect of nutritional and environmental conditions on the production and composition of rhamnolipids by Pseudomonas aeruginosa UG2. Microbiol. Res., 155: 1-8.

Miller, R.M., 1995. Biosurfactant-facilitated remediation of metal-contaminated soils. Environ. Health Persp., 103 (1): 59-62.

Mulligan, C.N., 2005. Environmental applications for biosurfactants. Environ. Pollut., 133 (2): 183-198.

Mulligan, C.N. and S. Wang, 2006. Remediation of a heavy metal-contaminated soil by a rhamnolipid foam. Eng. Geol., 85 (1-2): 75-81. 
Olvera, C., J.B. Goldberg, R. Sanchez and G. SoberonChavez, 1999. The Pseudomonas aeruginosa algC gene product participates in rhamnolipid biosynthesis. FEMS. Microbiol. Lett., 179 (1): 85-90.

Pagilla, K.R., A. Sood and H. Kim, 2002. Gordonia (norcadia) amarae foaming due to biosurfactant production. Water Sci. Technol., 46 (1-2): 519-524.

Patel, M., 2004. Surfactants based on renewable raw materials: Carbon dioxide reduction potential and policies and measures for the European Union. J. Ind. Ecol., 7 (3-4): 47-62.

Patel, M.N. and K.P. Gopinathan, 1986. Lysozyme-sentive bioemulsifier for immiscible organophosphorus pesticides. Applied Environ. Microbiol., 52 (5): 1224-1226.

Rahman, K.S.M., N. Vasudevan and P. Lakshmanaperumalsamy, 1999. Enhancement of biosurfactant production to emulsify different hydrocarbons. J. Environ. Pollut., 6 (2-3): 87-93.

Rahman, K.S.M., I.M. Banat, T.J. Rahman, T. Thayumanavan and P. Lakshmanaperumalsamy, 2002a. Bioremediation of gasoline contaminated soil by bacterial consortium amended with poultry litter, coir pith and rhamnolipid biosurfactant. Bioresour. Technol., 81 (1): 25-32.

Rahman, K.S.M., T.J. Rahman, S. McClean, R. Marchant and I.M. Banat, 2002b. Rhamnolipid biosurfactant production by strains of Pseudomonas aeruginosa using low-cost raw materials. Biotechnol. Prog., 18 (6): $1277-1281$.

Rahman, K.S.M., T.J. Rahman, P. Lakshmanaperumalsamy, R. Marchant and I.M. Banat, 2002c. Emulsification potential of bacterial isolates with a range of hydrocarbon substrates. Acta Biotechnol., 23 (4): 335-345.

Rahman, K.S.M., T.J. Rahman and P. Lakshmanaperumalsamy and I.M. Banat, 2002d. Occurrence of crude oil degrading bacteria in gasoline and diesel station soils. J. Basic Microb., 42 (4): 286-293.

Rahman, K.S.M., T.J. Rahman, Y. Kourkoutoas, I. Petsas, R. Marchant and I.M. Banat, 2003. Enhanced bioremediation of petroleum sludge using bacterial consortium amended with rhamnolipid and micronutrients. Bioresour. Technol., 90 (2): 159-168.

Rahman, K.S.M., G. Street, R. Lord, G. Kane and I.M. Banat, 2004. Bioremediation of Hydrocarbon Contaminated Gas Station Soil by a Bacterial Consortium. In: Coastal Environment Incorporating Oil Spill Studies, Brebbia, C.A., J.M.S. Perez, L.G. Andion and Y. Villacampa (Eds.). WIT Press, pp: 401-407.
Rahman, K.S.M., G. Street, R. Lord, G. Kane, T.J. Rahman, R. Marchant and I.M. Banat, 2006. Bioremediation of Petroleum Sludge Using Bacterial Consortium with Biosurfactant. In: Environmental Bioremediation Technologies, Singh, S.N. and R.D. Tripathi (Eds.). Springer Publication, pp: 391-408.

Raza, Z.A., A. Rehman, M.S. Khan and Z.M.Khalid, 2007. Improved production of biosurfactant by a Pseudomonas aeruginosa mutant using vegetable oil refinery wastes. Biodegradation, 18 (1): 115-121.

Rehn, H.J. and I. Reiff, 1981. Mechanisms and occurrence of microbial oxidation of long-chain alkanes. Adv. Biochem. Eng., 19: 175-216.

Robert, M., M.E. Mercade, M.P. Bosch, J.I. Parra, M.J. Espiny, M.A. Manaresa and J. Guinea, 1989. Effect of the carbon source on biosurfactant production by Pseudomonas aeruginosa 44TI. Biotechnol. Lett., 11 (12): 871-874.

Rosenberg, E., A. Zuckerberg, C. Rubinovitz and D.L Gulnick, 1979. Emulsifier Arthrobacter RAG-1: Isolation and emulsifying properties. Applied Environ. Microbiol., 37 (3): 402-408.

Rosenberg, E., 1993. Exploiting microbial growth on hydrocarbon: New markets. Trends Biotechnol., 11 (10): 419-424.

Rosenberg, E. and E.Z. Ron, 1999. High and lowmolecular-mass microbial surfactants. Applied Microbiol. Biotechnol., 52 (2): 154-162.

Schenk, T., I. Schuphan and B. Schmidt, 1995. Highperformance liquid chromatographic determination of rhamnolipid produced by Pseudomonas aeruginosa. J. Chromatogr. A., 693 (1): 7-13.

Sekelsky, A.M. and G.S. Shreve, 1999. Kinetic model of Biosurfactant-Enhanced hexadecane biodegradation by Pseudomonas aeruginosa. Biotechnol. Bioeng., 63 (4): 401-409.

Shafeeq, M., D. Yokub, Z.M. Khalid, A. Khan and K. Malik, 1989. Degradation of different hydrocarbons and production of biosurfactant by Pseudomonas aeruginosa isolated from coastal waters. J. Applied Microbiol. Biotech., 5: 505-510.

Shaw, D.G., 1992. The Exxon-Valdez oil-spill-ecological and social consequences. Environ. Conserv., 19 (3): 253-258.

Sheperd, K., J. Rockey, I.W. Sutherland and S. Roller, 1995. Novel bioemulsifiers from micro-organisms for use in foods. J. Biotechnol., 40 (3): 207-217.

Singer, M.E., 1985. Microbes and Oil Recovery. In: Bioresource Publications, Zajic, J.E. and E.C. Donaldson (Eds.). E1 Paso, Texas, pp: 19-38. 
Stanghellini, M.E. and R.M. Miller, 1997. Biosurfactants: Their identity and potential efficacy in the biological control of zoosporic plant pathogens. Plant Dis., 81 (1): 4-12.

Syldatk, C. and F. Wagner, 1987. Biosurfactants and Biotechnology. In: Marcel Dekker, Kosaric, N. and W.L. Carirns (Eds.). New York, pp: 26.

Thaniyavarn, J., N. Roongsawang, T. Kameyama, M. Haruki, T. Imanaka, M. Morikawa and S. Kanaya, 2003. Production and characterisation of biosurfactants from Bacillus licheniformis F2.2. Biosci. Biotech. Biochem., 67 (6): 1239-1244.

United Nations Framework Convention on Climate Change, 1997. Kyoto Protocol to the United Nations Framework Convention on Climate Change, Document FCCC/CP/1997; 7/Add1 http://www.unfccc.de).

Van Dyke, M.I., P. Couture, M. Brauer, H. Lee and J.T. Trevors, 1993. Pseudomonas aeruginosa UG2 rhamnolipid biosurfactants: Structural characterisation and their use in removing hydrophobic compounds from soil. Can. J. Microbiol., 39 (11): 1071-1078.
Van Ginkel, C.G., 1989. Complete degradation of xenobiotic surfactants by consortium of aerobic micro-organisms. Biodegradation, 7 (2): 151-164.

Veenanadig, N.K., M.K. Gowthaman and N.G.K. Karanth, 2000. Scale up studies for the production of biosurfactant in packed column bioreactor. Bioproc. Biosyst. Eng., 22 (2): 95-99.

Whalley, G., 1995. Green pressures are driving force behind surfactants. Manuf. Chem., 11: 38-40.

Wild, M., A.D. Caro, A.L. Hernandez and R.M. Miller, 1997. Selection and partial characterisation of a Pseudomonas aeruginosa mono-rhamnolipid deficient mutant. FEMS. Microbiol. Lett., 153 (2): $279-285$.

Wu, J. and L.K. Ju, 1998. Extracellular particles of polymeric material formed in n-hexadecane fermentation by Pseudomonas aeruginosa. J. Biotechnol., 59 (3): 193-202.

Zosim, Z., D.L. Gutnick and E. Rosenberg, 1982. Properties of hydrocarbon-in-water emulsions stabilised by Acinetobacter RAG-1 emulsan. Biotechnol. Bioeng., 24 (2): 281-292. 